\title{
Correlation Problem in Quaternary Stratigraphy, Prehistrory and Archaeostratigraphy in India: Role of 75 Ka Toba Ash Bed Markers
}

\author{
Acharyya SK* \\ Department of Geological Sciences, Jadavpur University, India \\ *Corresponding author: Acharyya SK, Emeritus Scientist, Department of Geological Sciences, Jadavpur University, Kolkata-32, India \\ Submission: 制September 11, 2017; Published: 阱 November 29, 2017
}

\begin{abstract}
Quaternary sediments in India mainly occur in river basins that host fossil bones, stone implements. Quaternary stratigraphy has significantly improved in correlation status after the recognition of the 75 ka Toba Ash Bed Marker. Older Quaternary sediments with reversed magnetic polarity have remained largely unstudied. Two gravel beds in Quaternary sequence can be biostratigraphically distinguished. The older is characterized by Mid Pleistocene fauna and it also includes the calvarium of Narmada man. A baby skull is human skull is also reported recently from Odai, Tamilnadu. The upper gravel and sand is characterized by extant vertebrate fauna and it also contains the Toba Ash Bed Marker. The gravel horizons are often undifferentiated due to non preservations of typical features.
\end{abstract}

\section{Introduction}

Quaternary sediments captures part of the story of the fauna that lived in different river valleys and forest, in the form of fossil bones, evidence left by ancestors of man in stone implements/ artifacts, recording remains of hominoid fossils attesting their anthropological development.

The discovery of 75 ka Toba Ash Bed Marker has immensely advanced the status of knowledge on correlation of Quaternary sediments and its stratigraphy. The Toba Ash Beds are easily recognizable by their typical megascopic and microscopic physicochemical features. Thus disconnected local reconstructions of the Quaternary sequences could be linked and stitched to give regional perspective. The Quaternary alluvium preserved in the river basins of the peninsular India has been the main stay of prehistoric archaeology. These stratified sediments enclose within themselves the chronological order of stone implements/artifacts which constitute important hard evidence to trace the early phase of cultural evolution of early-man in the Indian subcontinent. The correlation of intra- and inter-basinal Quaternary alluvium is problematic because of general absence of marker beds, imperfect faunal and/or cultural records, and problem in recognizing extent of their reworking. Radiometric dates like 14C are not applicable to older Quaternary sediments. There is ever increasing and improving of dating methods available to researchers e.g., Luminescence dating, Electron spin Resonance dating (ESR), Fission-track dating (FT), Uranium series dating, K-Ar dating, etc. Magnetic polarity stratigraphy or magneto stratigraphy is based on the temporal pattern of the reversals of the Earth's magnetic field as documented in geomagnetic polarity timescale. Applied to terrestrial sedimentary rocks compared to rocks at the mid oceanic ridges, it was found that continental sedimentation is generally discontinuous. The Geomagnetic Polarity Time Scale (GPTS) of the Quaternary is characterized by the normal Brunhes and the reverse Matuyama chron, of which the latter is interrupted by several subchrons. The chronology of early humans in Europe is intrinsically tied to the results of paleomagnetic investigations at all excavation sites. Many researchers have tried to interpret the age implications of various geochronological methods and magneto polarity studies that have been applied to recover absolute age for the Quaternary sections and recognize key beds if possible [1-4]. In many cases the inferences are contradictory. The entire data pool requires to be reprocessed together critically and in unbiased fashion.

\section{River Basins of Central India}

In Central India, Quaternary sediments occur as thick riverine sediments in central Narmada and Purna valleys. Other river vallies are shallow e.g., upper-mid Godavari, Wainganga, Pranhita, Pench, Kanhan, Son, Hasdo and upper Mahanadi. The Quaaternary section in the Narmada basin is divided into six formations, from top downwards they are Ramnagar, Banras, Hirdapur, Baneta, Sarajkund, Dhansi and Pilkarar. Tephra beds (equivalent of Toba) are present, as reworked younger beds in Hirdapur inter-layered with coarse basal sediments and in the Baneta below with brown 
paleosol [5,6]. Interestingly, the Dhansi Formation records reverse magnetic polarity indicating they belong to the Lower Plaeistocene stratigraphy and of $0.73 \mathrm{Ma}$ age [6]. A lot remains to be done for systematic dating of Quaternary sequences and magneto-polaric study over potentially older Quaternary sections.

\section{Isampur and Bori sites}

Based on fresh condition of tools, their occurrence in association with factory site, ESR date on two fossil teeth of associated herbivore yielding $1.27 \mathrm{Ma}$ age, other dates on other material, the Isampur (16030'N:76029'E) (Figure 1) site was claimed to be one of the oldest site in the Indian subcontinent [7]. Fragmentary vertebrates from Isampur have not identified any Middle Pleistocene fauna to specific level (Figure 1) [8].

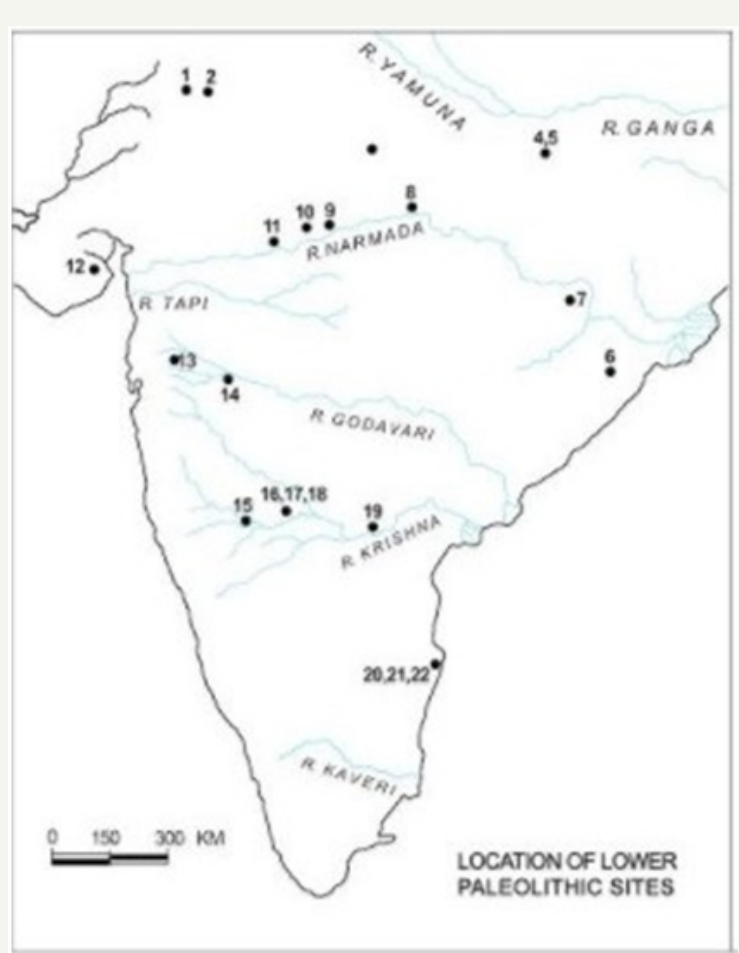

Figure 1: Lower Paleolithic sites in Peninsular India.

Site locations: 1- Jayal; 2-Didwana; 3-Lalitpur; 4- Sihawal (Son valley); 5-Nakhjat Khur (Narmada valley); 6-Kuliana (Narmada valley); 7-Pasra; 8- Mahadeo Piaria; 9- Adamgarh; 10-Bhimbaetka; 11-Durkadi nala; 12-Samadhiala; 13 Gangapur; 13A-Bori; 14-Chirki-on-pravara; 15- Anganwadi; 16-Hunsgi; 17Yadiapur; 18-Isampur; 19- Nagarjunkonda; 20- Attirampakkam; 21-Vadamadurai; 22-Gudiyan.

The ash bed at Bori (19007'N:74006E) (Figure 1 \& 2) was regarded to be old and possibly the oldest. Additional studies on geochemical characterization of Toba Ash Beds and fission track dating of its two samples from Pawlaghat in Narmada and Gandhi gram in Purna basin reaffirmed that all Toba Ash occurrences in Indian subcontinent belong to 75 ka youngest Toba events (Westgate, et al., 1998). The Acheulian tools from Bori occurring in close association with the Toba ash appear to be reworked material in younger sediments. The evidence of reworking of stone implements has often remained unrecognized. Therefore, the discovery of oldet Acheulian culture in Indian subcontinent, whether at Isampur or at Bori based on primitive character alone as yet remains elusive. Some more Acheulian sites have been located or have been further studied. Significant find has been from Attirampakkam area of Tamil Nadu [site 20] (Figure 1), South India, recording Mesolithic and upper Palaeolithic industry in Late Pleistocene period in stratified context and with prised presence of a fossil skull of baby human at Odai corresponding to Homo sapience (archaic) [4]. The ferricrust cover over the fossil skull has been subjected to thermo-luminescence dating, which calculated to 0.166 my corresponding to Middle Pleistocene.

\section{Middle and Late Pleistocene Gravel beds}

The Paleolithic stone implements in Indian subcontinent generally occur in two biostratigraphically recognizable horizons. The older gravel bed characterized by locally preserved Mid Pleistocene fauna, till now provides the oldest biostratgraphic record of Lower Palaeolithic tools. This gravel bed has also yielded the fossilized calvarium of early man (Sonakia, 1984). The gravel bed is assigned late Mid Pleistocene age (200-300 ka) based on the evolutionary grade of Cuon alpines tripathi and the archaic Homo sapience- like character of Narmada calvarium [9].

The younger gravel and overlying sand is assigned Upper Pleistocene age based on the presence extant mammalian assemblage, presence of $75 \mathrm{ka}$ Toba Ash Bed Marker and association of Acheulian and Middle Palaeolithic tools. However, the distinction between the two gravel horizons becomes obscure as diagnostic mammalian faunal elements are rarely preserved.

\section{Correlation status of Quaternary stratigraphy in Indian} subcontinent

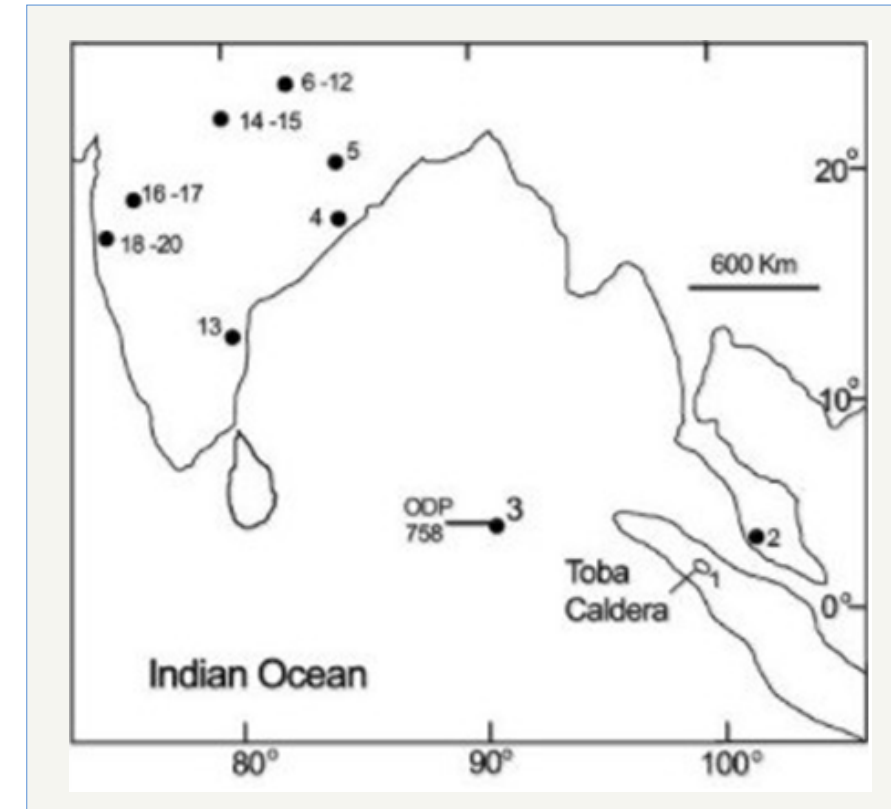

Figure 2: Map showing location of Toba caldera and locations of Toba Ash in Indian subcontinent.

Site locations: Serdong, Malaysia location 2; ODP site 758 location 3, it recorded Layers A, C and E representing YTT,MTT 
and OTT respectively; Toba Ash Beds locations in the Indian peninsula, locations: 4 Goguparu, Vansadhara river, Odisha; location 5 Pitamohal Mahanadi river section, Odisha; location 6-12 Son river section; location 14 Pawlaghat, Narmada river section; location 15 Guruwara, Narmada river section; location 16 Gandhigram, Purna river section; location 17 Purna basin; location 18-19 Bori, near Pune; location 20 Kukdi river, Pune.

There has been a near quantum jump in status of correlation of Quaternary sediments from Indian subcontinent after the recognition of $75 \mathrm{ka}$ Youngest Toba Ash Bed Marker horizon (Figure 2) [9]. It not only provides correlative marker for continental alluvium from different river basins but also makes possible correlation between continental and open sea sediments in the Bay of Bengal, Indian Ocean, Arabian Sea and South China Sea $[9,10]$. Although partly reworked, they are generally first cycle sediments and represent isochronous event marker [11].

The Odai find becoming most potential hominid site in India hold great future promise.

\section{References}

1. Mishra S, Venkatesan TR, Rajagura SN, Somayajulu BLK (1995) Earliest Acheulian industry from Peninsular India. Current Anthropology 36(5): 847-851.

2. Deo S, Mishra S, Rajaguru SN, Ghate S (2007) Antiquity of Acheulian culture in upland Maharastra: a geoarcheological approach. In:
Sankhayan AR, Rao VR (Eds.), Human origin Genome and people of India. Anthropological Survey of India and Allied Pub, Calcutta, India, pp. 292-308.

3. Sangode JS, Mishra S, Deo S (2007) Magneto stratigraphy sediments associated with some Toba tephra and Acheulian artifacts bearing localities in the western and central India. Gondwana Magazine Special Issue 10: 111-121.

4. Sarkar J (2011) Presence of Early Pleistocene Acheuline hominins in South India. Curr Sci 101: 1003-1005.

5. Basu PK, Biswas S, Acharyya SK (1987) Late Quaternary ash beds from Son and Narmada basins. Madhya Pradesh, Indian Minerals 41: 66-72.

6. Tiwari M (2012) Quaternary geology of Central India. Geol Surv India, Misc Pub 64: 625-635.

7. Paddayya K, Blackwell BAB, Jhaldiyal R, Petraglia MD, Fevrier S, et al. (2002) Curr Sc 83: 641-647.

8. Acharyya SK (2003) Recent findings on the acheulian of isampur excavations and its dating. Curr Sci 84: 127-128.

9. Acharyya SK, Basu PK (1993) Toba Ash on the Indian subcontinent and its implications for correlation of Late Pleistocene alluvium. Quaternary Research 40(1): 10-19.

10. Pattan JN, Shane P (1999) Excess aluminium in deep sea sediments of the Central Indian Basin. Marine Geol 161(2-4): 247-247.

11. Acharyya SK, Basu PK (1994) Reply: Toba Ash on the Indian subcontinent and its implications for correlation of Late Pleistocene alluvium. Quaternary Research 41: 401-402. 